\title{
The U.S. Shale Oil Revolution and the Behavior of Commodity Prices
}

\author{
Afees A. Salisu a and Idris A. Adediran \\ ^Centre for Econometric and Allied Research, University of Ibadan, Nigeria \\ -Department of Economics, Obafemi Awolowo University, Nigeria
}

Submitted: February 26, 2018 • Accepted: June 13, 2018

\begin{abstract}
The United States is committed to technological improvements in horizontal drilling and hydraulic fracturing in its drive of toppling the world's leading oil producers by the mid-2020s and evolving into a net oil exporter by 2030. Consequently, these technological innovations revolutionized the U.S. oil sector and the international oil market with increasing relevance of the shale oil and attendant shock spillovers to financial and commodity markets. Upon these attractions and consistent with evidence in the literature, we trace the oil price and commodity price dynamics to the shale oil revolution using a recursive structural VAR model of the shale supply shocks. In line with the standard practice of ensuring sensitivity of results, we conduct analyses such as impulse responses, forecast-error variance decomposition, and historical decompositions to accommodate energy and nonenergy commodity components. We show, in addition to the popular view in the extant literature, that the shale oil revolution is not only associated with the recent oil price plunge, but also responsible for the tumble in the total energy-based commodity prices with crude oil price being just a component.
\end{abstract}

JEL classification: C32, E31, E32, Q02, Q43

Keywords: U.S. shale oil revolution, oil shocks, commodity prices, SVAR

*Corresponding Author. Email: aa.salisu@cear.org.ng 


\section{Introduction}

Due to unabated reliance of the world's economy on fossil fuels in the face of sustained energy demand worldwide, the shale oil revolution came about through advances in horizontal drilling and hydraulic fracturing, a technological leap heralding improvement in exploration, extraction, processing, and drilling oil and gas from previously nonrecoverable sources (shales) (Wakamatsu and Aruga, 2013; Melikoglu, 2014; Bilgili et al., 2016; Zendehboudi and Bahadori, 2017a,b). The technological developments use these techniques to facilitate the extraction of oil and gas from shales in economically viable quantities. The process of hydraulic fracturing involves pumping water, sand, and chemicals at high pressure to fracture the shale formation and create artificial permeability to release the oil and gas from shale erstwhile trapped in tight formations (Ansari, 2017; Zendehboudi and Bahadori, 2017a,b). Interestingly, the process allows for long-term production given opportunity for large-scale exploitation of existing shale wells (Middleton et al., 2017).

In addition, the shale oil revolution represents a giant step in the goal of making the United States the world's leading crude oil producer, ahead of the top OPEC producer, Saudi Arabia, by the mid-2020s and evolving into a net oil exporter by 2030 (see the International Energy Agency projection of 2012). In this vein, the technological change in the oil and gas extractive industry has sped-up the rate of production in the United States; has seen the U.S. domestic oil production surge from 5 million barrels per day in 2008 to more than 9 million barrels per day in recent months; is responsible for about half of U.S. total crude oil production in 2015, and reduced the U.S. oil imports from OPEC to a 28-year low (Bataa and Park, 2017; Khan, 2017). It has also engendered cheaper energy prices for residential, commercial, and industrial consumers (due to relative lower cost of shale oil production in the United States relative to most of the world) and improved targets to meet domestic consumption. Thus, with the United States hedging closer to energy independence coupled with its ability to wrestle power from OPEC, the shale oil revolution could represent an additional win in its global hegemony. These came with consequences for oil-dependent economies such as Yemen, Egypt, Qatar, Saudi Arabia, Nigeria, and Algeria who once enjoyed heavy patronage from the United States energy supply needs, but now grapple with lower prices (see Khan, 2017, for more).

In the literature, studies on the shale oil revolution, as well as the possible spillover effects, are gradually emerging. The few related empirical papers are those conducted by Mănescu and Nuño (2015); Bilgili et al. (2016); Ansari (2017); Bataa and Park (2017) and Paris (2017) and Monge et al. (2017) and their findings offer some insightful motivations for further empirical inquiry. For instance, Bataa and Park (2017) and Monge et al. (2017) find that the shale oil revolution has a greater potential to influence global oil prices. On the other hand, Mănescu and Nuño (2015) reveal that the impact of the shale oil revolution on 
the GDP of oil importers is more likely to be minimal given that the consequences of the expected increases in U.S. oil supply due to the shale oil revolution filter through (consumer) prices. These evidences point to the possible connection of the shale oil revolution with oil and consumer markets and their price evolution. We therefore extend the literature further to capture the probable response of the commodity market to shocks due to the U.S. shale oil revolution. This exercise is borne out of the established nexus between the international crude oil and commodity markets in the extant literature.

Theoretically, the connection between oil price changes and the commodity markets stems from, one, the increasing evidence of swings in international oil prices and global commodity prices; two, the evidence of volatility spillover from the oil market to nonenergy commodity markets in recent times; three, the liberalization of capital flows stimulating increased integration between commodity markets so that commodity prices tend to respond to the same shock; and four, the financialization and integration of commodity markets exposing it to potential contagion risks (Ji and Fan, 2012; Hegerty, 2016; Bastianin et al., 2016; Algieri and Leccadito, 2017). Empirically, the nexus has been largely limited to the interaction between energy and agricultural commodity markets. Studies such as Liu (2014); Wang et al. (2014); Chen (2015); Fernandez-Perez et al. (2016); Lucotte (2016); Pal and Mitra (2018) report either a direct impact of crude oil or comovements with the commodities. Also, there are corroborative evidences suggesting that some economic policies or energy developments can buffer the interdependence between oil prices and world commodity prices (e.g., Natanelov et al., 2011; Paris, 2017).

The foregoing discussions are insightful for the present study. Although further empirical motivations for the present study are bared in the succeeding section, we argue here on the basis of the previous claims that the U.S. energy development policy resulting in the shale oil revolution could influence the oil-commodities dynamics. The focus of the present paper, therefore, is to trace the shale oil shocks through oil price and commodity price indices. There are notable attractions for this intellectual exercise. First, the shale oil revolution represents a significant leap especially for the United States in its quest to improve crude oil production capacity to overtake Saudi Arabia as the leading global oil producer (see the International Energy Agency projection of 2012). Second, the shale oil revolution has been linked to the recent oil market imbalances and oil price fluctuations even as it affords the United States considerable advantage in the international oil scene (Hamilton, 2014; Mănescu and Nuño, 2015; Arezki and Blanchard, 2014; Bilgili et al., 2016; Baumeister and Kilian, 2016; Ansari, 2017; Bataa and Park, 2017).

The motivation to direct our research focus on the shale oil revolution is further enhanced when we stress the distinction between shale and conventional crude oil. Shale oil, by definition is a member in the family of crude oil, although it is formed in tight formations 
and explored with unconventional methods of fracturing and hydraulic drilling (Wakamatsu and Aruga, 2013; Aguilera, 2014; Melikoglu, 2014; Mănescu and Nuño, 2015; Bilgili et al., 2016; Monge et al., 2017; Zendehboudi and Bahadori, 2017a,b; Tan and Barton, 2017). It is therefore safe to refer to shale oil as an unconventional crude oil (Zendehboudi and Bahadori, 2017a). There are evidences in recent times that the United States has been able to significantly increase its total crude oil supply chiefly due to the shale oil revolution and this oil sector revolution in the Unites States has not only evoked oil price responses, but also induced reactions from OPEC regarding production quotas (Khan, 2017; Bataa and Park, 2017; Genc, 2017; Kim, 2018). These arguments point to the particular relevance of unconventional crude oil, hence, by implication, our research focus on the oil-commodities dynamics must necessarily emanate from unconventional oil and trace the transmission of shocks via the conventional crude oil.

Remarkably, with these motivations forming the backbone of the research methodology, we are able to establish responses for conventional oil output and oil price, particularly due to the shale oil supply shocks, and trace the transmission of such shocks to energycontaining and nonenergy commodity prices. The rest of the paper is structured as follows. The next section provides further motivation of the study. Section 2 describes the research methodology. Section 3 presents the preliminary analysis of results before the main discussion of results in Section 4. Section 5 concludes the paper.

\section{Motivations for Studying the Shale Oil-Commodity Prices Volatility Nexus}

The empirical analysis of the shale oil-commodity prices contagion has remained unexplored in the extant literature despite arguments of contagion spillovers from the conventional oil market to other nonenergy markets. There are, however, evidences to show that the impact of the shale oil revolution can be felt in the real economy (e.g., Mănescu and Nuño, 2015; Bilgili et al., 2016).

Mănescu and Nuño (2015) analyze the impact of the shale oil revolution on oil prices and economic growth with a general equilibrium model of the world oil market. Results suggest that most of the expected increase in U.S. oil supply due to the shale oil revolution has already been incorporated into prices and that it will produce an additional increase of $0.2 \%$ in the GDP of oil importers in the period 2010-2018.

Further, Bilgili et al. (2016) examine the impacts of the shale oil revolution on industrial production in the United States. The dynamic ordinary least squares estimator explores that shale oil production has a positive effect on industrial production. Besides that, evidence 
from the Granger causality test show that shale gas production causes industrial production in the United States.

Other empirical evidences in the extant literature address the impact of conventional oil markets to other financial and commodity markets. In terms of volatility spillover to financial markets, considerable works have been done in the past to connect oil price changes with stock price/returns (e.g., Hamilton, 1996; Sadorsky, 1999; Kilian, 2009; Nandha and Faff, 2008; Miller and Ratti, 2009; Chen, 2010; Aloui et al., 2013; Salisu and Oloko, 2015). More recently, Bastianin et al. (2016) study the effects of oil price shocks on the stock market volatility of the G7 countries. Findings show that stock market volatility does not respond to oil supply shocks, but rather to demand shocks.

Mohaddes and Pesaran (2017) confirm an unstable relationship between oil and equity prices during the 1946-2016 period. Further, Nadal et al. (2017) investigate the time-varying impacts of demand and supply oil shocks on correlations between changes in oil prices and stock market returns. The findings indicate that demand shocks positively affect the correlations between oil prices and stock market returns during and after the 2007/08 financial markets volatility and at the height of uncertainties about Chinese economic growth in 2015.

Away from oil price volatility spillover to financial markets, considerable studies have been done on contagion effects of conventional oil markets to nonfinancial commodities markets. One of these is Nazlioglu et al. (2013) who examine volatility spillover between oil prices and the prices of agricultural commodities (prices of corn, soybeans, wheat, and sugar), conducting analysis for the pre-crisis period (01 January 1986 to 31 December 2005) and the post-crisis period (01 January 2006 - 21 March 2011). The findings show evidence of no volatility spillover between the oil market and agricultural commodities markets in the precrisis period, but establish interdependence between the markets afterward. With structural breaks cointegration and nonlinear causality tests, Fowowe (2016) also shows that agricultural commodity prices in South Africa are neutral to global oil prices.

Like Nazlioglu et al. (2013); Wang et al. (2014) also find that oil shocks explain marginal variations in agricultural commodity prices before the food crisis in 2006-2008, whereas in the post-crisis period their explanatory abilities become much higher.

In light of the present study, Ji and Fan (2012) examine the influence of the oil market on nonenergy commodity markets before and after the 2008 financial crisis. The results reveal that the oil market exerts significant volatility spillover effects on nonenergy commodity markets, which demonstrates its core position among commodity markets. This position is also in tune with Algieri and Leccadito (2017) who show that commodity markets generate contagion risks, which are mainly triggered by financial factors for the energy market and that there are spillovers from energy to food markets. 


\section{Methodology}

Essentially, this study considers the strength of the U.S. economy as a major player that exogenously influences the world oil price with its large crude oil production, be it conventional crude oil or shale oil from unconventional sources. On the one hand, this is corroborated by evidences showing that the impact of the shale oil revolution can be felt in the real economy (e.g., Mănescu and Nun̋o, 2015; Bilgili et al., 2016). On the other hand, it reflects the influence of the conventional oil market fundamentals on real variables, such as commodity prices as argued from the evidence of volatility spillover from the oil market to energy commodity markets (Ji and Fan, 2012; Hegerty, 2016; Bastianin et al., 2016; Algieri and Leccadito, 2017).

Thus, the modelling highlights the role of U.S. shale oil supply and studies the linkage with crude oil output, oil price (measured with the West Texas Intermediate), and commodity prices. In line with the theoretical specification consistent with Kilian (2009), Wang et al. (2014), Baumeister and Kilian (2016), Mohaddes and Raissi (2015), Mohaddes and Pesaran (2016), Khan (2017), Algieri and Leccadito (2017), and Bataa and Park (2017) we adopt a structural VAR model consisting of four endogenous variables, namely, U.S. shale oil production, U.S. crude oil supply, international oil price, and the all-commodity prices of the form: ${ }^{1}$

$$
\Pi_{0} y_{t}=\alpha+\sum_{j=1}^{p} \Pi_{j} y_{t-1}+\varepsilon_{t}
$$

where $y_{t}$ is a $4 \times 1$ column vector of endogenous variables, $y_{t-1}$ is the vector of lagged values of endogenous variables up to lag order $p$, and $\varepsilon_{t}$ is a vector of serially and mutually uncorrelated structural shocks containing variances of U.S. shale oil supply, U.S. crude oil production, oil price, and the all-commodity prices such that:

$$
\begin{aligned}
& y_{t}=\left(\text { US shale }_{t}, \text { UScrude }_{t}, \text { oilp }_{t}, \text { comm }_{t}\right)^{\prime} \\
& \varepsilon_{t}=\left(\varepsilon_{\text {USshale }, t}, \varepsilon_{\text {UScrude }, t}, \varepsilon_{\text {oilp }, t}, \varepsilon_{\text {comm }, t}\right)^{\prime} \\
& E\left(\varepsilon_{t} \varepsilon_{t}^{\prime}\right)=\Sigma
\end{aligned}
$$

where $\Pi_{j}$ is a $4 \times 4$ matrix of the SVAR parameters and $\Pi_{0}$ is a lower triangular matrix of recursive short run impulse responses. Inheriting the characteristics of $\Pi_{0}, \Pi_{0}^{-1}$ also possesses a recursive structure, hence, the reduced form of the errors designated as $\xi_{t}$ can be decomposed thus:

\footnotetext{
${ }^{1}$ For robustness, we substitute nonfuel commodity prices for the all-commodity prices because the energy component in the latter may influence the outcome of the analysis due to possible correlation with the WTI oil price in the specification.
} 


$$
\xi_{t}=\Pi_{0}^{-1} \varepsilon_{t}=\left[\begin{array}{l}
\xi_{t}^{U S s h a l e} \\
\xi_{t}^{U S c r u d e} \\
\xi_{t}^{\text {oilp }} \\
\xi_{t}^{\text {comm }}
\end{array}\right]=\left[\begin{array}{cccc}
a_{11} & 0 & 0 & 0 \\
a_{21} & a_{22} & 0 & 0 \\
a_{31} & a_{32} & a_{33} & 0 \\
a_{41} & a_{42} & a_{43} & a_{44}
\end{array}\right]\left[\begin{array}{l}
\xi_{t}^{\text {USshalesupplyshock }} \\
\xi_{t}^{\text {UScrudesupplyshock }} \\
\xi_{t}^{\text {oilpriceshock }} \\
\xi_{t}^{\text {commoditypriceshock }}
\end{array}\right]
$$

This specification is based on a recursive model that allows us to trace the transmission of shocks emanating from the U.S. shale oil revolution across crude oil supply, oil price, and commodity prices. The structural VAR model is analyzed with the tools of impulse response functions and historical decompositions. In our specification, the shock responses could be derived through the representation in (4) and the historical decomposition in (5):

$$
\begin{gathered}
y_{t}=\left(\sum_{j=0}^{p} \Pi_{j}^{*} L^{j}\right)^{-1} \varepsilon_{t}=\left(\sum_{k=0}^{\infty} \varphi_{k} L^{k}\right) \varepsilon_{t}=\left(\sum_{k=0}^{\infty} \varphi_{k} \varepsilon_{t-k}\right) \\
y_{t}=\sum_{i} \sum_{k=0}^{\infty} \varphi_{i, k}^{(k)} \varepsilon_{i, t-k}
\end{gathered}
$$

\section{Data and Preliminary Analyses}

The shale oil revolution being the centrepiece of this paper necessitates need for data on U.S. shale oil production. We utilize monthly data set on shale oil production across the seven U.S. oil-rich regions: Anadarko region, Appalachia region, Bakken region, Eagle Ford region, Haynesville region, Niobrara region, and Permian region. This data allows us to explore the probable effects of shocks due to (shale) oil supply following the revolution in the energy sector. We trace the effect of these shocks first to the total U.S. crude oil supply, then to oil and commodity prices, given the prior hints in the literature that the shocks have perceptible influence on energy and nonenergy prices. Consequently, we sought data on total crude oil production in the United States, oil price (Western Texas Intermediate), and commodity price indices (all components and nonfuel, excluding the energy fuel component). The data scope spans from 1st January 2007 to 31st December 2017, yielding exactly 132 observations for each series (Table 1). The intuition behind this scope is that it captures the start date of shale oil production in commercial quantities as one of the institutional responses to the global financial crisis at that time.

It is customary in empirical studies of this nature to explore the historical information of the series from statistical and graphical perspectives to provide insights into the nature and distribution of the series individually, as well as understand the likely comovements or divergence among the variables of interest. In essence, we assess the descriptive statistics of 
the series of interest, including the mean, standard deviation, skewness, and kurtosis (Table 2 ), and also provide the graphical analyses (Figures 1 to 4) as a foundation to build our study. Based on the descriptive statistics, all the series are widely spread given the standard deviation values with respect to the mean values. Commonplace, also, is that the series deviate from normal distribution, with the exception of the nonfuel commodity price index. A salient observation here, however, is the observed difference in the distributions between the all-commodities price index and the nonfuel commodities price index. This indicates that the analysis based on the two series may differ given that the price index, excluding energy components, is positively skewed and almost normally distributed, whereas the allcommodities price index behaves otherwise. ${ }^{2}$

In Figures 1 to 4, we plot the U.S. shale oil production series against each of the variables expected to respond to the shock: total crude oil production, the oil price, and commodity price indices (all- and nonfuel commodity price index respectively). The shale and crude oil outputs appear to move together and experience convergence, especially starting around 2014. This phenomenon is also noted for the relationship between the shale series and the oil, general, and nonfuel commodity prices. It is also noteworthy that the three commodity prices mirror one another and, as such, share some common characteristics. As common with inflation measures, the commodity prices witness spikes whereas, on the other hand, oil productions appear to soar with time to converge with shale oil production series around 2014. This observation agrees with positions in the literature that the oil supply shocks may actually have a hand in the oil price plunge of that period (Hamilton, 2014; Arezki and Blanchard, 2014; Mănescu and Nun̋o, 2015; Baumeister and Kilian, 2016; Bataa and Park, 2017; Ansari, 2017; Kilian, 2017; Khan, 2017).

To be properly guided in the estimation process, we examine the time series properties of the series using a battery of stationarity and nonstationarity tests. These tests are conducted on the transformed series of the variables; they are transformed as growth rates in line with the seminal paper from which this study draws inspiration (Kilian, 2009). The analysis entails testing for nonstationarity; that is, the presence of a unit root in the series employing the Augmented Dickey-Fuller (ADF) and Phillips-Perron (PP) tests (Table 3). These are confirmed with the Kwiatkowski-Phillips-Schmidt-Shin (KPSS) test, which specifically tests for stationarity in the series (Table 4). Taken together, results from the analyses reveal that the Augmented Dickey-Fuller (ADF) and the Phillips-Perron (PP) tests indicate a rejection of the nonstationarity null hypotheses at a level showing that the series are integrated of the order of zero. For confirmation, we also rely on the Kwiatkowski-Phillips-Schmidt-Shin stationarity test. In the same vein, with results from the KPSS tests, we could not reject

\footnotetext{
${ }^{2}$ This is found to be true at the estimation stage where the Impulse Response graphs produce dissimilar results for the all-commodity prices containing energy components and the nonfuel prices devoid of same.
} 
the null of stationarity for the series at level. Hence, the ADF, PP, and KPSS tests point to the stationarity of the series at level. Thus, by intuition, these results taken together with submissions in the graphical analysis indicate evidence of cointegration among the variables.

\section{Discussion of Results}

In this study, we are concerned with the analysis of the U.S. energy and international commodity markets dynamics where we subject the ensuing multivariate model to oil production shocks, namely, shocks from U.S. shale oil production. We adopt the structural VAR (SVAR hereinafter) framework to trace the shock transmission mechanism from the shale oil revolution as the source of oil supply shocks through the total U.S. crude production to the different commodity prices: energy price (oil price), nonenergy (nonfuel) price, and the composite commodity prices (the all-commodity prices comprising fuel, nonfuel, and other prices). As instructed in Breitung (1998), we are guided by relevant theoretical constructs in our specification of the SVAR model dynamics. In essence, we dealt with a recursive SVAR where we impose relevant restrictions on the system of equations to trace the impacts of the shock in the VAR system coming from the shale oil supply shocks. Based on the instantaneous impacts associated with the interrelationship between oil supply and oil price and the direct spillover to commodity prices, we work with a short SVAR, where current values of the variables affect each other to show contemporaneous effects of the shock pass-through.

Our VAR model is, therefore, a recursive dynamic structural model where commodity prices respond to oil price changes and oil supply shocks (conventional and unconventional oil supply), in that order. In line with the extant literature in this area (e.g., Kilian, 2009, and others), we apply the SVAR methodology to achieve three major feats. First, we produce the graphical representations of the impulse response functions (hereafter, IRFs) to show the average responses of the target variables (all-commodity prices and oil and nonfuel prices) to structural shocks from the shale oil revolution. Second, we construct forecast error variance decompositions (hereafter, FEVDs) to measure the average contribution of the structural

shock across the system. Third, we generate historical decompositions (hereafter, HDs) to determine the cumulative contribution of the structural shocks to the evolution of the target variables through time. We focus on shale oil supply shocks (LSHALE) through responses from crude oil output (LCRUDE), oil price (LOILP), and all-commodity prices (LCOMM) and follow it up by replacing all-commodity prices with nonfuel prices (LNONFUEL) for robustness. We attend to the foregoing in the listed order in subsequent sections. 


\subsection{The Impulse Response Functions}

We begin the analysis by assessing the tools that tell us how the shale oil supply shocks reverberate through the SVAR system. The IRFs partly assist in this regard (Figures 5 to 8). In simple language, the IRFs measure the effects of these oil supply shocks on the other endogenous (target) variables. More technically, the IRFs show the effects of the shale oil production shocks on the adjustment path of the target variables (arranged on one hand as crude oil supply, oil price, and all-commodity prices, and on the other hand arranged as crude oil supply, oil price, and nonfuel prices). The IRFs capturing the shale oil supply revolution shock transmission are contained in Figures 5 to 8 . The impacts of the supply shocks on the target variables differ; the effects of the shale supply shocks stayed longer on crude oil supply and nonfuel prices before dying out, in comparison with oil price and the commodity price with an energy component (all-commodity prices). The shale oil revolution evokes instant positive responses from the total crude oil output before dying out around the 10th period. However, the U.S. shale oil production shock induces negative responses from the three prices, although the response of nonfuel commodity prices appears to be more lasting. Thus, we cannot ignore the glaring semblance where the responses of oil price to the shale oil revolution mirror that of all-commodity prices to the same shock. The graphical view appears like a plunge in those prices (oil and all-commodity prices) as a result of the shale oil supply shock. The foregoing reveals the strength of the U.S. energy sector in transmitting shocks that could alter the world energy prices given that the shale oil revolution appears to alter the energy prices. We seek further insights from the forecast error variance decompositions in the next section.

\subsection{The Forecast Error Variance and Historical Decompositions (FEVDs)}

To further shed light on the shale oil supply shocks transmission, we turn to the FEVDs (Tables 5 and 6). Like the IRFs, the FEVDs serve as a supporting tool to assess the shock transmission through the VAR system. In our specific case, the FEVDs measure the contribution of the orthogonal (uncorrelated) forecast error variance of the shale oil supply shocks attributable to itself or to the other (target) variables (crude oil supply, oil price, and commodity prices). Tables 5 and 6 represent the FEVDs results for the transmission of shocks emanating from U.S. shale oil supply shock through total crude oil supply to either oil price and all-commodity prices or to oil price and nonfuel commodity prices, respectively. As expected, the results in Table 5 show that shale oil accounts for predominant variation of own shock with significant shock spillover to conventional oil, but infinitesimal shock spillover to either oil price or commodity prices. Results from Table 6 also show overwhelming preva- 
lence of own shock in the variance decomposition of shale oil supply shock with major shock spillover to conventional crude oil supply. The implication of these results is that the impacts of the shale oil revolution are more pronounced on the supply side of the energy market and are, therefore, slightly transmitted to the international oil price and commodity prices.

Building on the previous discussions, which situate the shale oil revolution, an unconventional crude oil, as a relevant shock in the evolutionary path of conventional crude oil, the price of oil, and commodity prices (both energy related and nonenergy related), we extend our analysis to cover information provided by the historical decompositions (as obtained in Figures 9 to 12). By definition, the historical decompositions show the extent to which the structural shocks (from the shale oil revolution) explains the historical fluctuations in the endogenous variables (conventional oil, oil price, and the all- and nonfuel- commodity prices). In other words, we use the HD to trace the genesis of the shock impacts on the endogenous variables and, therefore, provide information on the cumulative effect of the shale oil supply shock on each of the endogenous variables. These are apparent in Figures 9 to 12. In these figures, the lines representing shale oil shock are significantly visible; hence, the shale oil revolution appears to explain significant portions of the fluctuations in the crude oil output, the international oil price, and the commodity prices.

\section{Conclusion}

The United States has committed to technological improvements in its drive to topple the world's leading crude oil producer by the mid-2020s and evolving into a net oil exporter by 2030. The resulting technological change in the oil and gas extractive industry aimed at furthering this goal has, among others, sped up the rate of crude production in the United States; has seen a surge in the U.S. domestic oil production; is responsible for all-time low U.S. oil imports from OPEC; and has enhanced employment and income generation in resourcerich communities. These feats have been attributed to the shale oil revolution. Based on these attractions around the shale oil revolution, we extend discussion from a body of literature (e.g., Kilian, 2009; Hamilton, 2014; Arezki and Blanchard, 2014; Mănescu and Nuño, 2015; Baumeister and Kilian, 2016; Ansari, 2017; Kilian, 2017; Bataa and Park, 2017), linking the recent oil price tumble to the U.S. shale oil revolution by capturing the possible spillover of such disturbances to commodity prices. Hence, we work with a structural VAR model that traces the recursive transmission dynamics from the oil supply shocks through oil price linkage with fundamentals in the commodity market. In this exercise, we explore the impulse response, forecast-error variance decomposition and historical decomposition functions for the total and U.S. shale oil production shocks. We provide robust empirical evidences to show that the shale oil revolution has indeed enhanced the U.S. oil supply capabilities and is 
in reality associated with the recent plunge in not only oil price, but all-commodity prices, i.e., commodity prices with energy components.

\section{References}

Aguilera, R. F. (2014). Production costs of global conventional and unconventional petroleum. Energy Policy, 64:134 - 140.

Algieri, B. and Leccadito, A. (2017). Assessing contagion risk from energy and non-energy commodity markets. Energy Economics, 62:312 - 322.

Aloui, R., Hammoudeh, S., and Nguyen, D. K. (2013). A time-varying copula approach to oil and stock market dependence: The case of transition economies. Energy Economics, $39: 208-221$.

Ansari, D. (2017). OPEC, Saudi Arabia, and the shale revolution: Insights from equilibrium modelling and oil politics. Energy Policy, 111:166 - 178.

Arezki, R. and Blanchard, O. (2014). Seven questions about the recent oil price slump. IMFdirect-The IMF Blog, 22.

Bastianin, A., Conti, F., and Manera, M. (2016). The impacts of oil price shocks on stock market volatility: Evidence from the G7 countries. Energy Policy, 98:160 - 169.

Bataa, E. and Park, C. (2017). Is the recent low oil price attributable to the shale revolution? Energy Economics, 67:72 - 82.

Baumeister, C. and Kilian, L. (2016). Understanding the Decline in the Price of Oil since June 2014. Journal of the Association of Environmental and Resource Economists, 3(1):131-158.

Bilgili, F., Koçak, E., Bulut, U., and Sualp, M. N. (2016). How did the US economy react to shale gas production revolution? An advanced time series approach. Energy, 116:963-977.

Breitung, J. (1998). Neuere Entwicklungen auf dem Gebiet ökonometrischer Strukturmodelle: Strukturelle Vektorautoregressionen. Technical report, Discussion Papers, Interdisciplinary Research Project 373: Quantification and Simulation of Economic Processes.

Chen, P. (2015). Global oil prices, macroeconomic fundamentals and China's commodity sector comovements. Energy Policy, 87:284 - 294.

Chen, S.-S. (2010). Do higher oil prices push the stock market into bear territory? Energy Economics, 32(2):490 - 495 . 
Fernandez-Perez, A., Frijns, B., and Tourani-Rad, A. (2016). Contemporaneous interactions among fuel, biofuel and agricultural commodities. Energy Economics, 58:1 - 10.

Fowowe, B. (2016). Do oil prices drive agricultural commodity prices? Evidence from South Africa. Energy, 104:149 - 157.

Genc, T. S. (2017). OPEC and demand response to crude oil prices. Energy Economics, $66: 238-246$.

Hamilton, J. (2014). Oil prices as an indicator of global economic conditions. Econbrowser.

Hamilton, J. D. (1996). This is what happened to the oil price-macroeconomy relationship. Journal of Monetary Economics, 38(2):215 - 220.

Hegerty, S. W. (2016). Commodity-price volatility and macroeconomic spillovers: Evidence from nine emerging markets. The North American Journal of Economics and Finance, $35: 23-37$.

Ji, Q. and Fan, Y. (2012). How does oil price volatility affect non-energy commodity markets? Applied Energy, 89(1):273 - 280. Special issue on Thermal Energy Management in the Process Industries.

Khan, M. I. (2017). Falling oil prices: Causes, consequences and policy implications. Journal of Petroleum Science and Engineering, 149:409 - 427.

Kilian, L. (2009). Not All Oil Price Shocks Are Alike: Disentangling Demand and Supply Shocks in the Crude Oil Market. American Economic Review, 99(3):1053-69.

Kilian, L. (2017). The Impact of the fracking boom on Arab oil producers. Energy Journal, 38(6):137-160.

Kim, M. S. (2018). Impacts of supply and demand factors on declining oil prices. Energy, $155: 1059-1065$.

Liu, L. (2014). Cross-correlations between crude oil and agricultural commodity markets. Physica A: Statistical Mechanics and its Applications, 395:293 - 302.

Lucotte, Y. (2016). Co-movements between crude oil and food prices: A post-commodity boom perspective. Economics Letters, 147:142 - 147.

Melikoglu, M. (2014). Shale gas: Analysis of its role in the global energy market. Renewable and Sustainable Energy Reviews, 37:460 - 468. 
Middleton, R. S., Gupta, R., Hyman, J. D., and Viswanathan, H. S. (2017). The shale gas revolution: Barriers, sustainability, and emerging opportunities. Applied Energy, 199:88 95.

Miller, J. I. and Ratti, R. A. (2009). Crude oil and stock markets: Stability, instability, and bubbles. Energy Economics, 31(4):559 - 568.

Mohaddes, K. and Pesaran, M. H. (2016). Country-specific oil supply shocks and the global economy: A counterfactual analysis. Energy Economics, 59:382 - 399.

Mohaddes, K. and Pesaran, M. H. (2017). Oil prices and the global economy: Is it different this time around? Energy Economics, 65:315 - 325.

Mohaddes, K. and Raissi, M. (2015). The U.S. oil supply revolution and the global economy. IMF Working Paper WP/15/259.

Monge, M., Gil-Alana, L. A., and de Gracia, F. P. (2017). U.S. shale oil production and WTI prices behaviour. Energy, 141:12 - 19.

Mănescu, C. B. and Nuño, G. (2015). Quantitative effects of the shale oil revolution. Energy Policy, 86:855 - 866 .

Nadal, R., Szklo, A., and Lucena, A. (2017). Time-varying impacts of demand and supply oil shocks on correlations between crude oil prices and stock markets indices. Research in International Business and Finance, 42:1011 - 1020.

Nandha, M. and Faff, R. (2008). Does oil move equity prices? A global view. Energy Economics, 30(3):986 - 997.

Natanelov, V., Alam, M. J., McKenzie, A. M., and Huylenbroeck, G. V. (2011). Is there co-movement of agricultural commodities futures prices and crude oil? Energy Policy, 39(9):4971- 4984 .

Nazlioglu, S., Erdem, C., and Soytas, U. (2013). Volatility spillover between oil and agricultural commodity markets. Energy Economics, 36:658 - 665.

Pal, D. and Mitra, S. K. (2018). Interdependence between crude oil and world food prices: A detrended cross correlation analysis. Physica A: Statistical Mechanics and its Applications, 492:1032 - 1044 .

Paris, A. (2017). On the link between oil and agricultural commodity prices: Do biofuels matter? International Economics. 
Sadorsky, P. (1999). Oil price shocks and stock market activity. Energy Economics, 21(5):449 $-469$.

Salisu, A. A. and Oloko, T. F. (2015). Modeling oil price-US stock nexus: A VARMA-BEKKAGARCH approach. Energy Economics, 50:1-12.

Tan, S. H. and Barton, P. I. (2017). Optimal shale oil and gas investments in the United States. Energy, 141:398 - 422 .

Wakamatsu, H. and Aruga, K. (2013). The impact of the shale gas revolution on the U.S. and Japanese natural gas markets. Energy Policy, 62:1002 - 1009.

Wang, Y., Wu, C., and Yang, L. (2014). Oil price shocks and agricultural commodity prices. Energy Economics, 44:22 - 35.

Zendehboudi, S. and Bahadori, A. (2017a). Chapter Seven - Properties of Shale Oil. In Zendehboudi, S. and Bahadori, A., editors, Shale Oil and Gas Handbook, pages 231 - 283. Gulf Professional Publishing.

Zendehboudi, S. and Bahadori, A. (2017b). Chapter Ten - Shale Oil and Gas: Current Status, Future, and Challenges. In Zendehboudi, S. and Bahadori, A., editors, Shale Oil and Gas Handbook, pages 357 - 404. Gulf Professional Publishing. 
Figure 1: Trends in US Shale and US Crude Oil Production

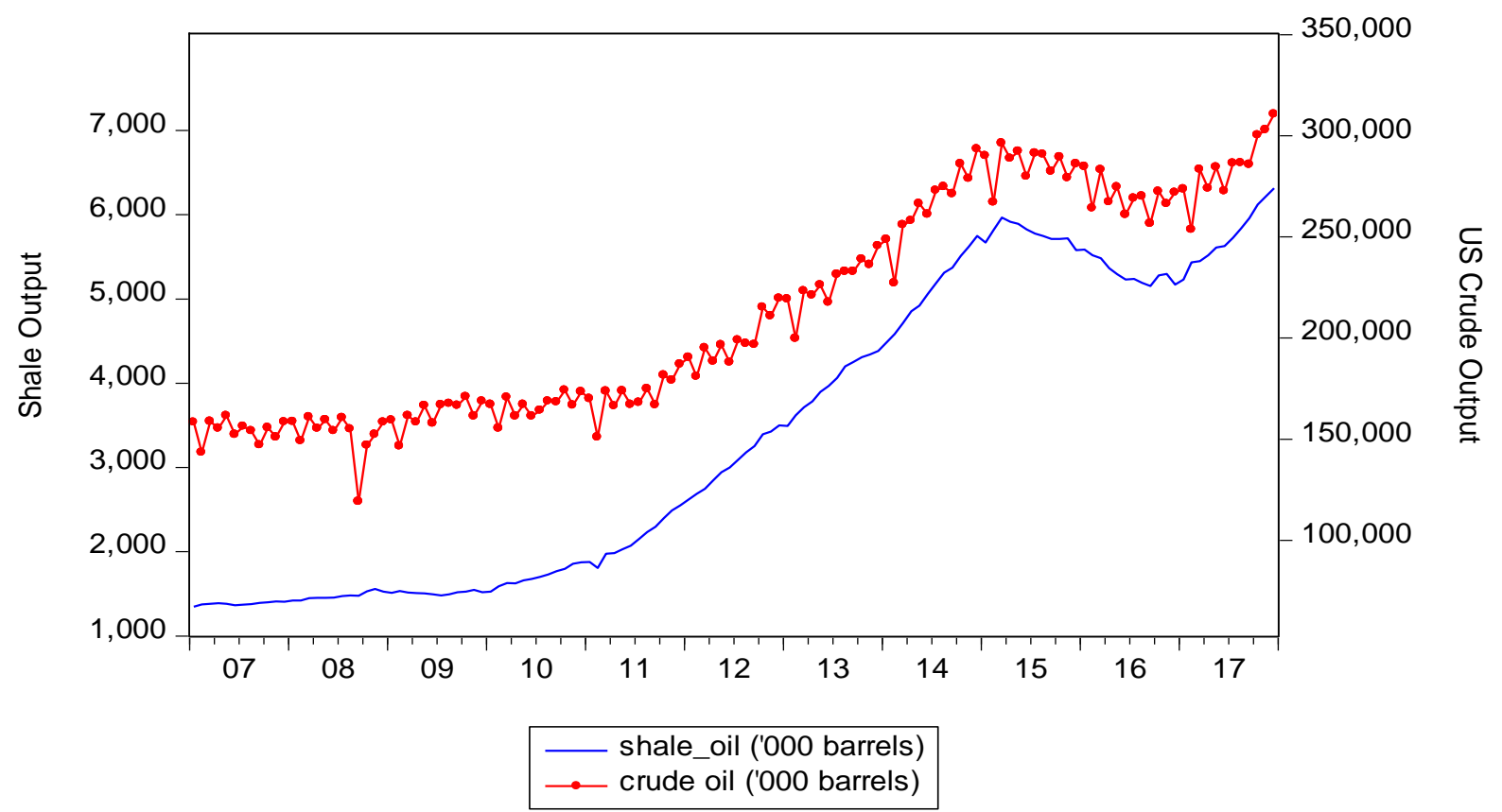

Figure 2: Trends in US Shale Production and Oil Price

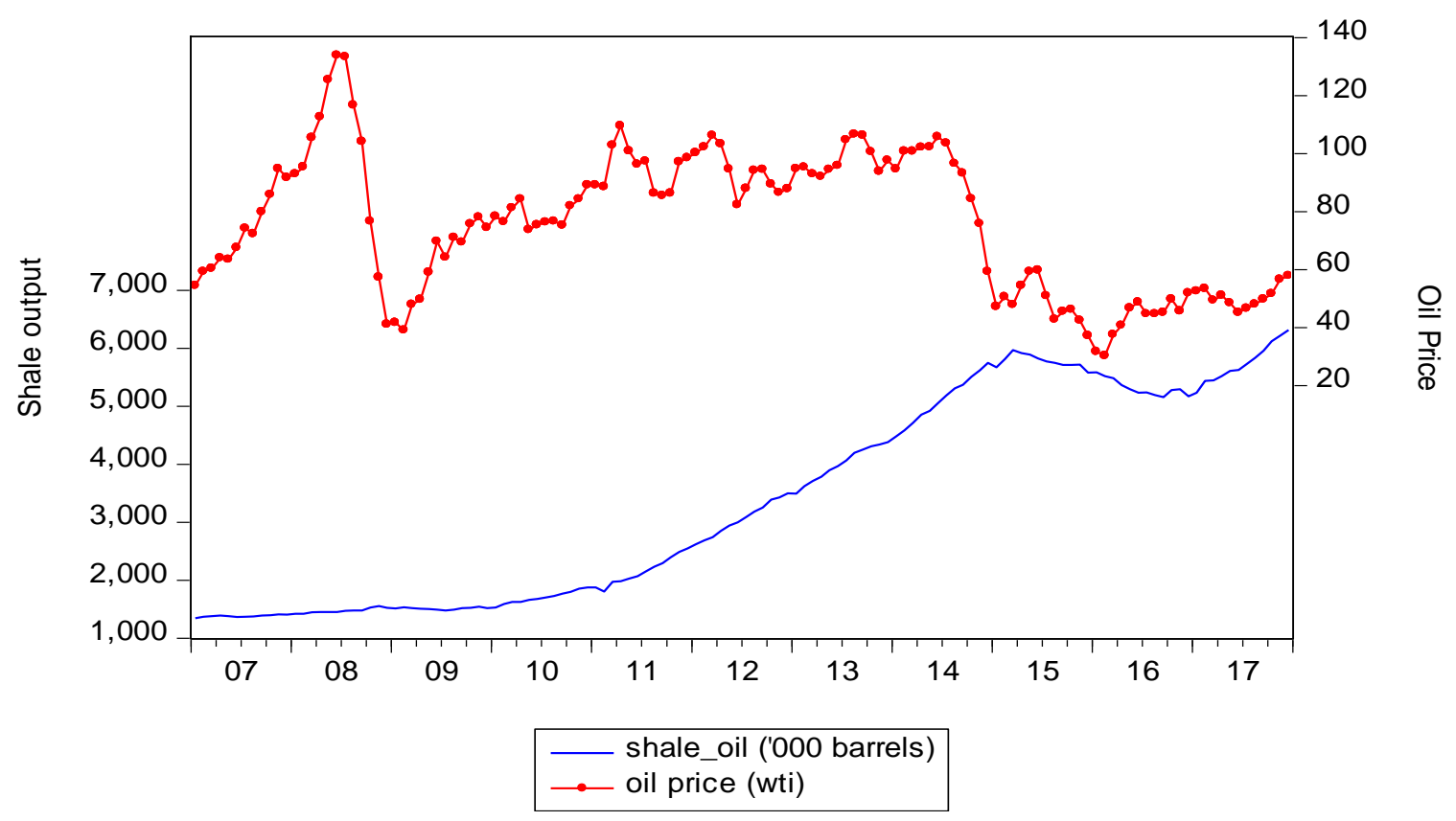


Figure 3: Trends in US Shale Production and Commodity Price Index

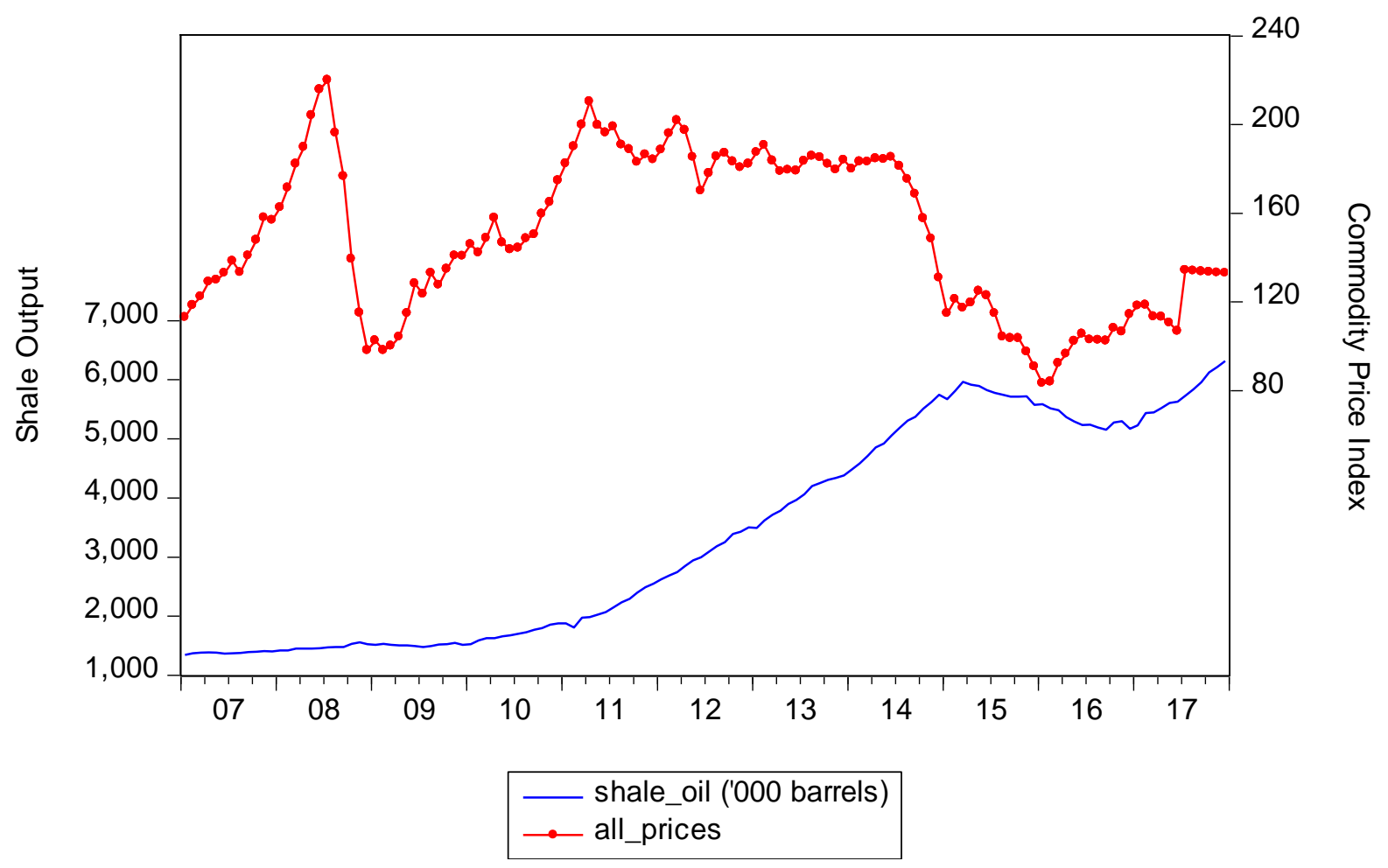

Figure 4: Trends in US Shale Production and Nonfuel Price Index

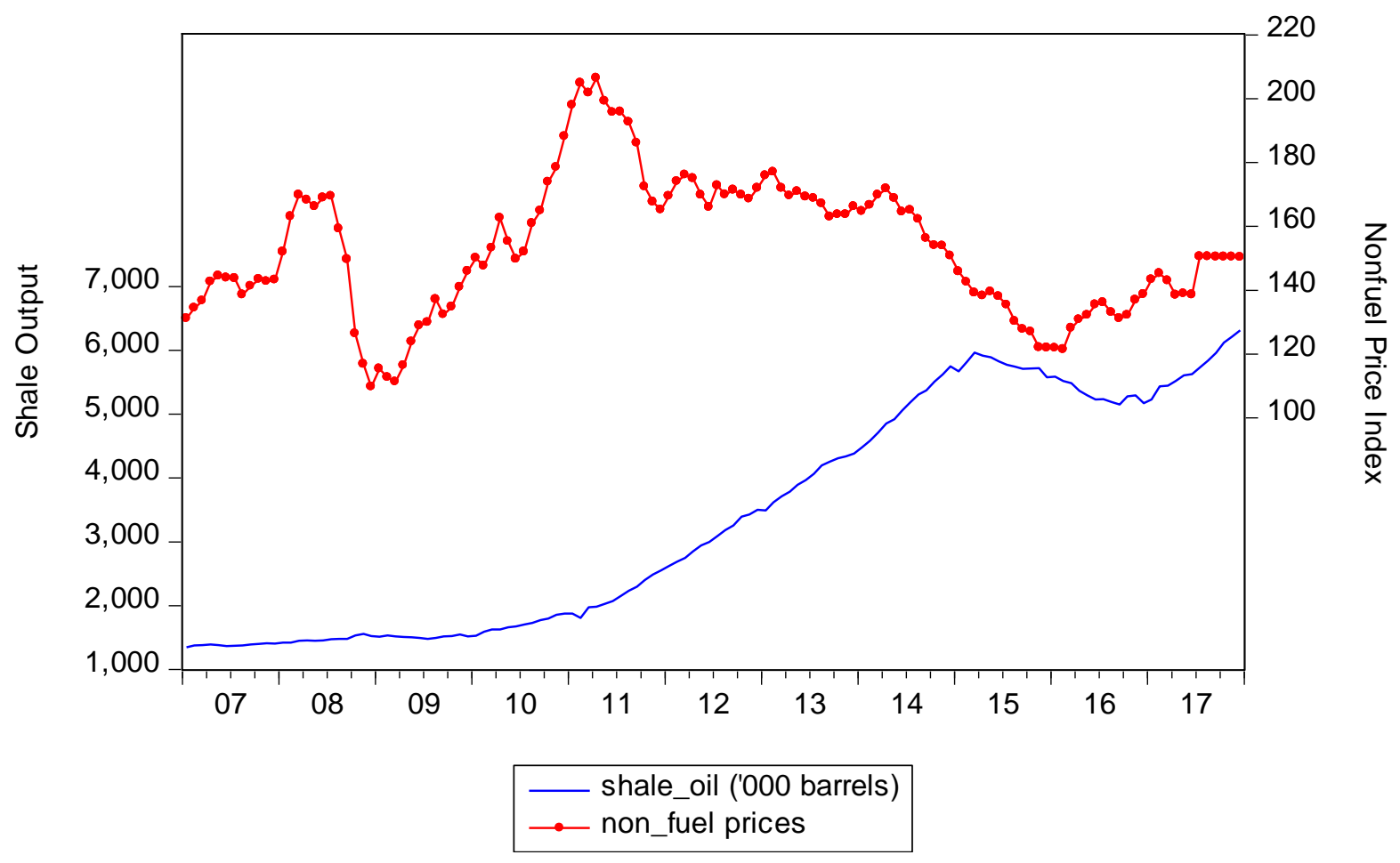


Figure 5: Impulse Response of US Crude from US Shale Production

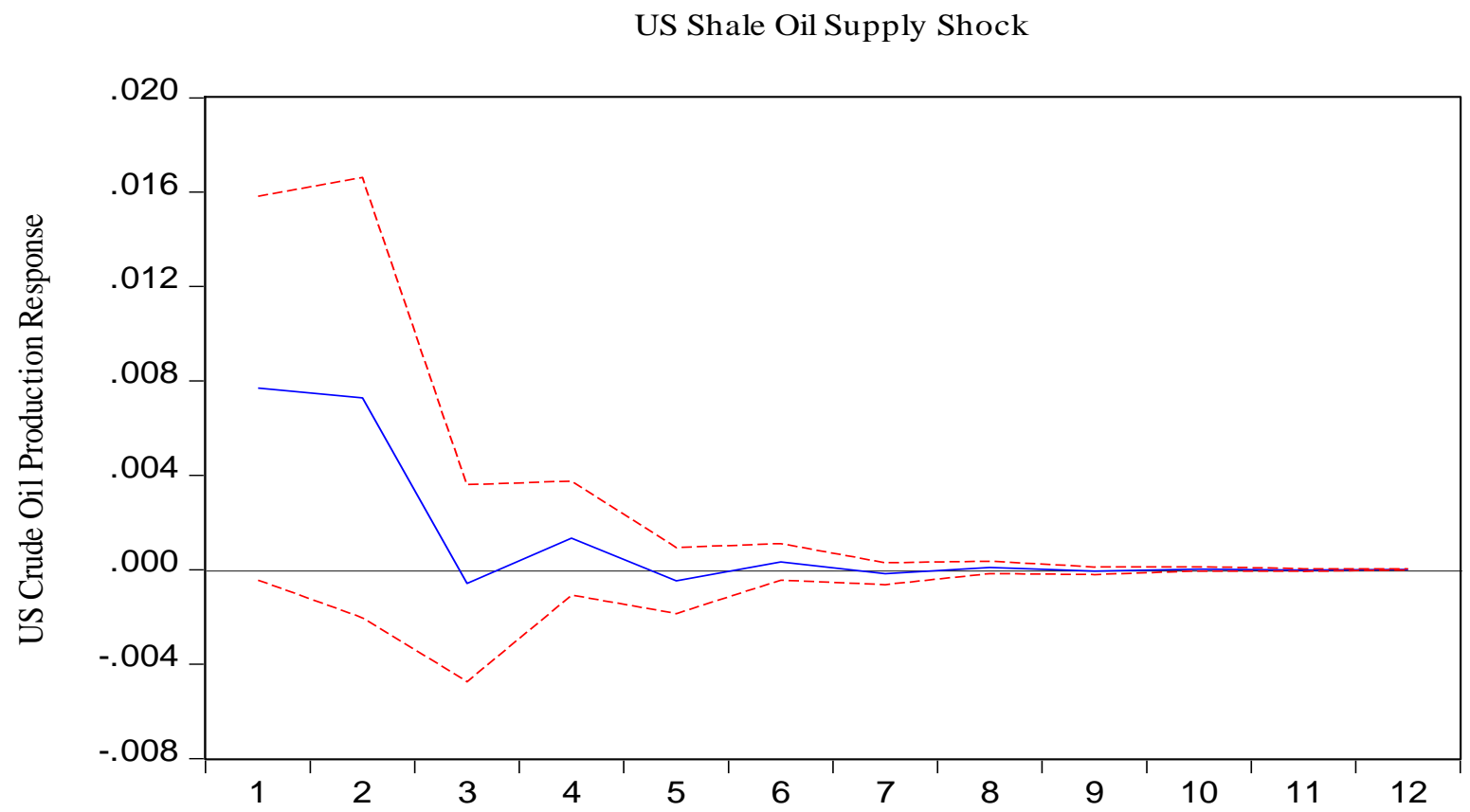

Figure 6: Impulse Response of Oil Price from US Shale Production US Shale Oil Supply Shock

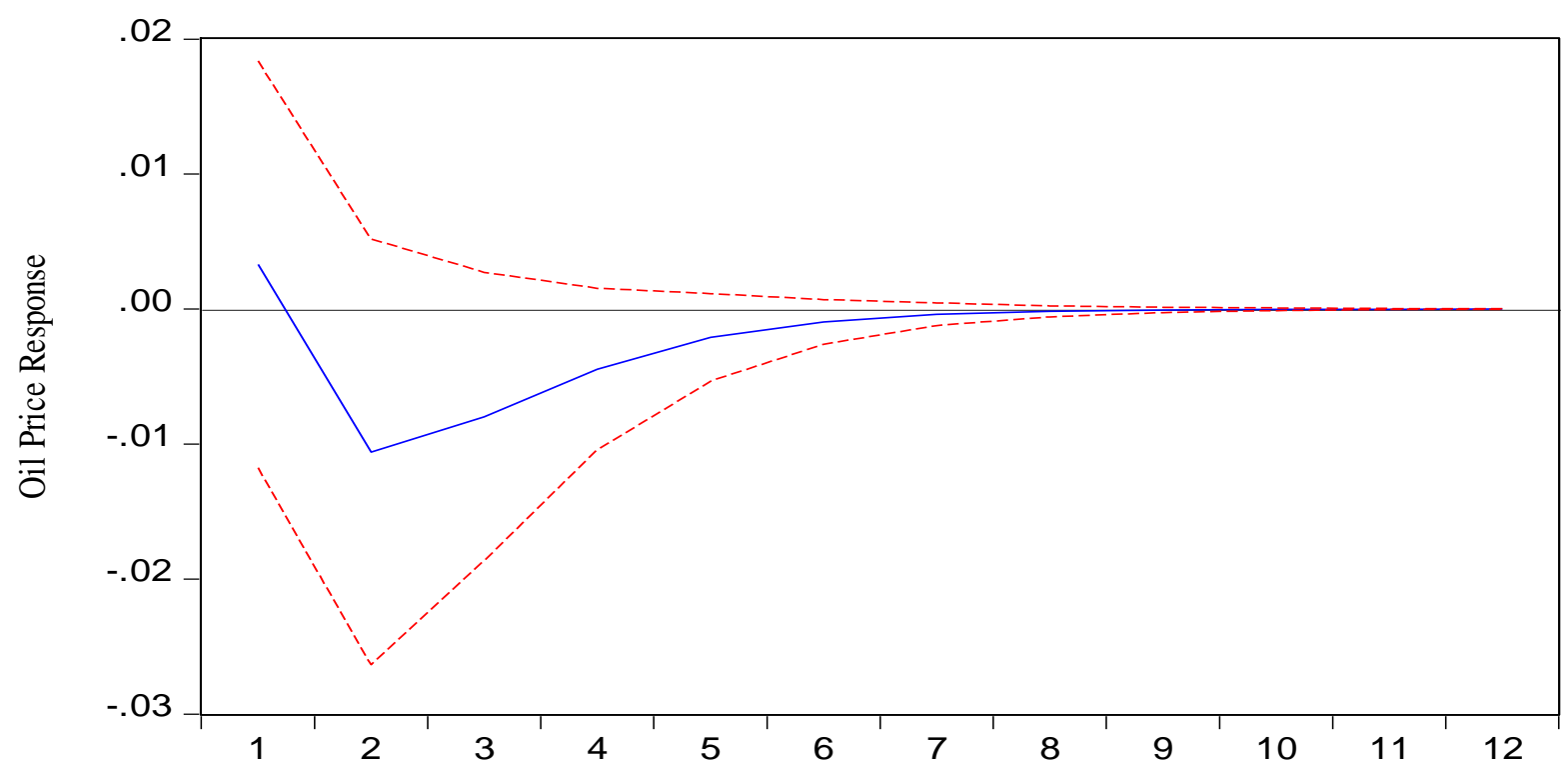


Figure 7: Impulse Response of Commodity Prices from US Shale Production

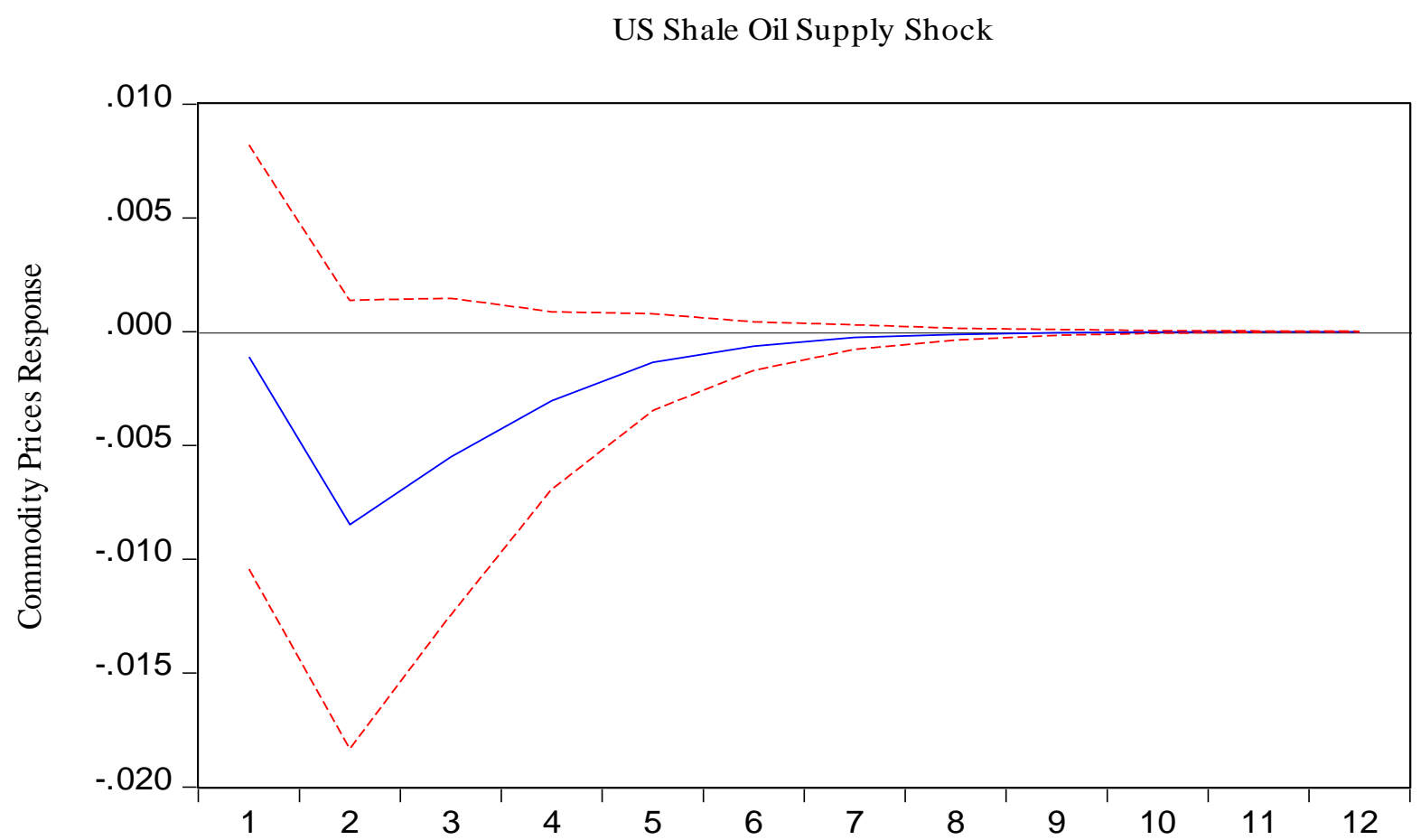

Figure 8: : Impulse Response of Nonfuel Prices from US Shale Production

US Shale Oil Supply Shock

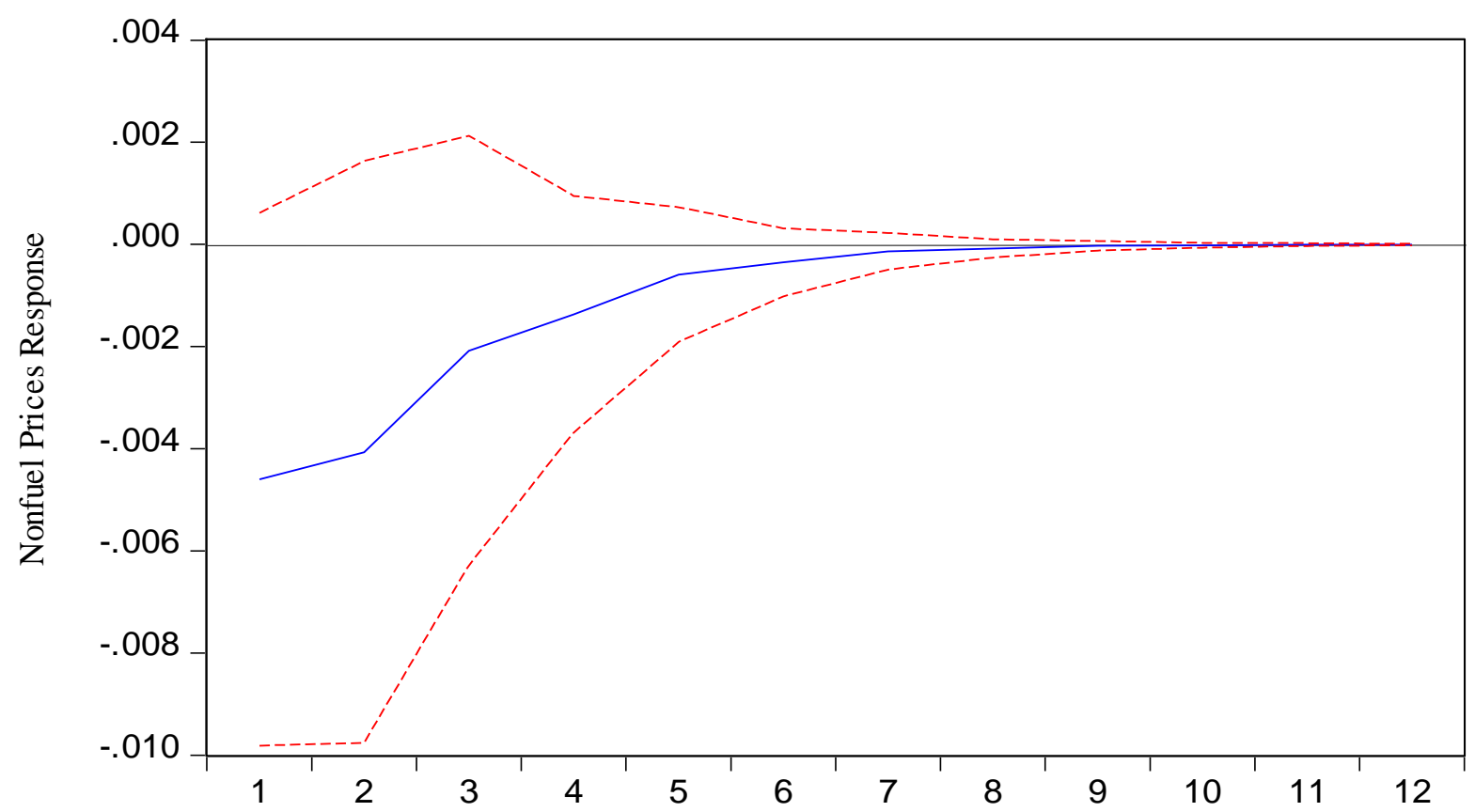


Figure 9: Historical Decomposition of Crude Oil from Shale Oil

LCRUDE from LSHALE

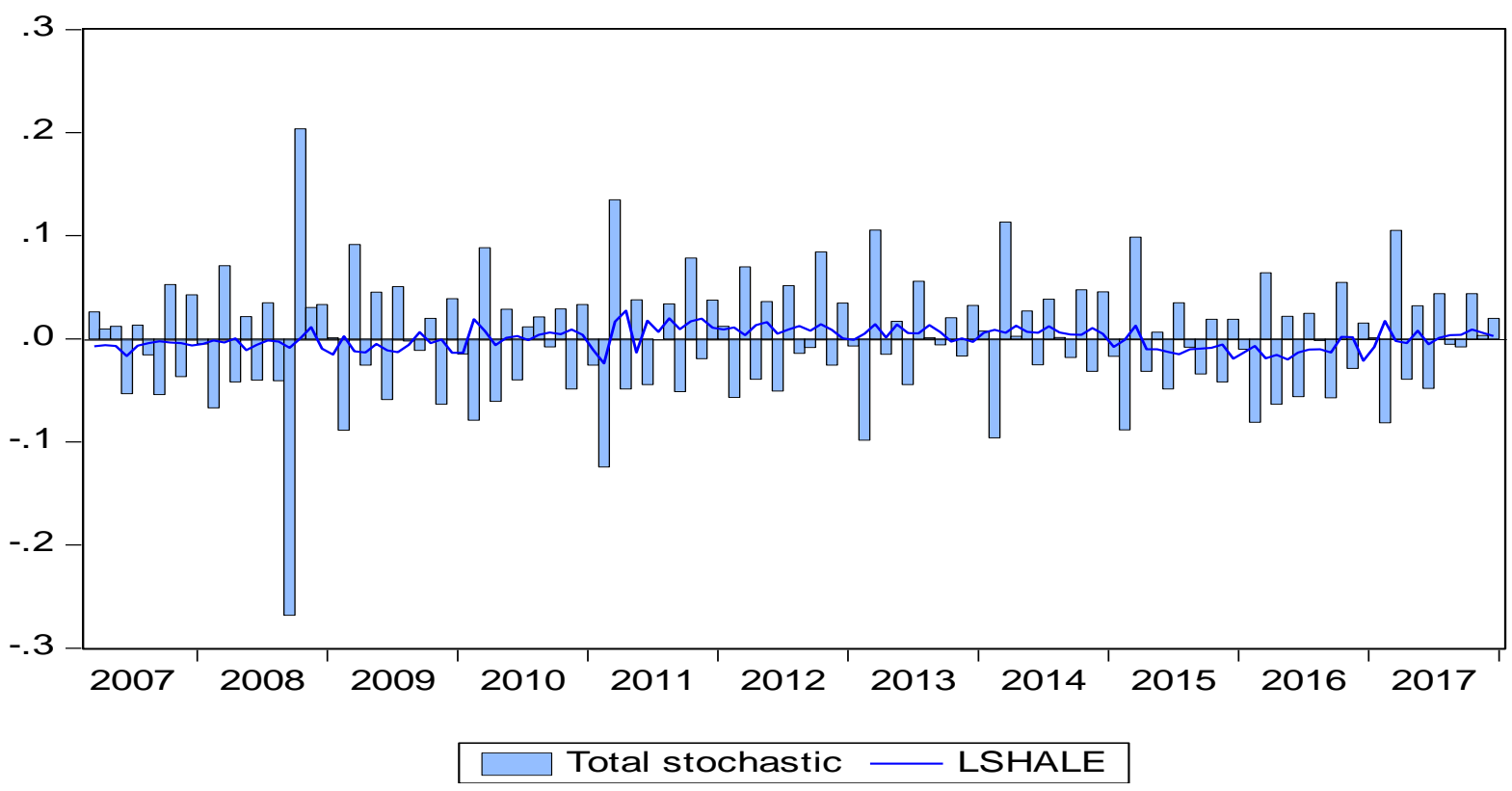

Figure 10: Historical Decomposition of Oil Price from Shale Oil

\section{LOILP from LSHALE}

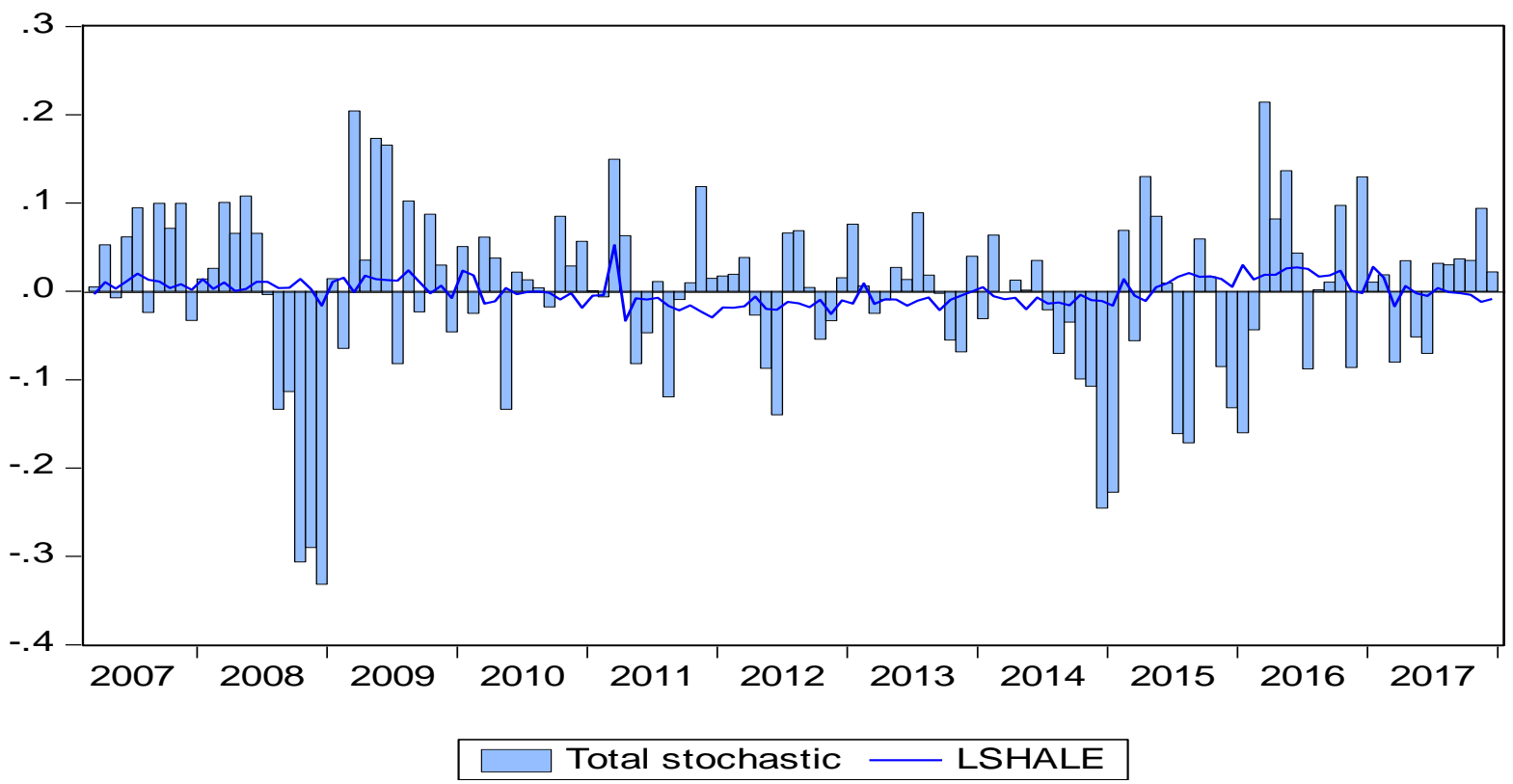


Figure 11: Historical Decomposition of All-Commodity Prices from Shale Oil

LCOMM from LSHALE

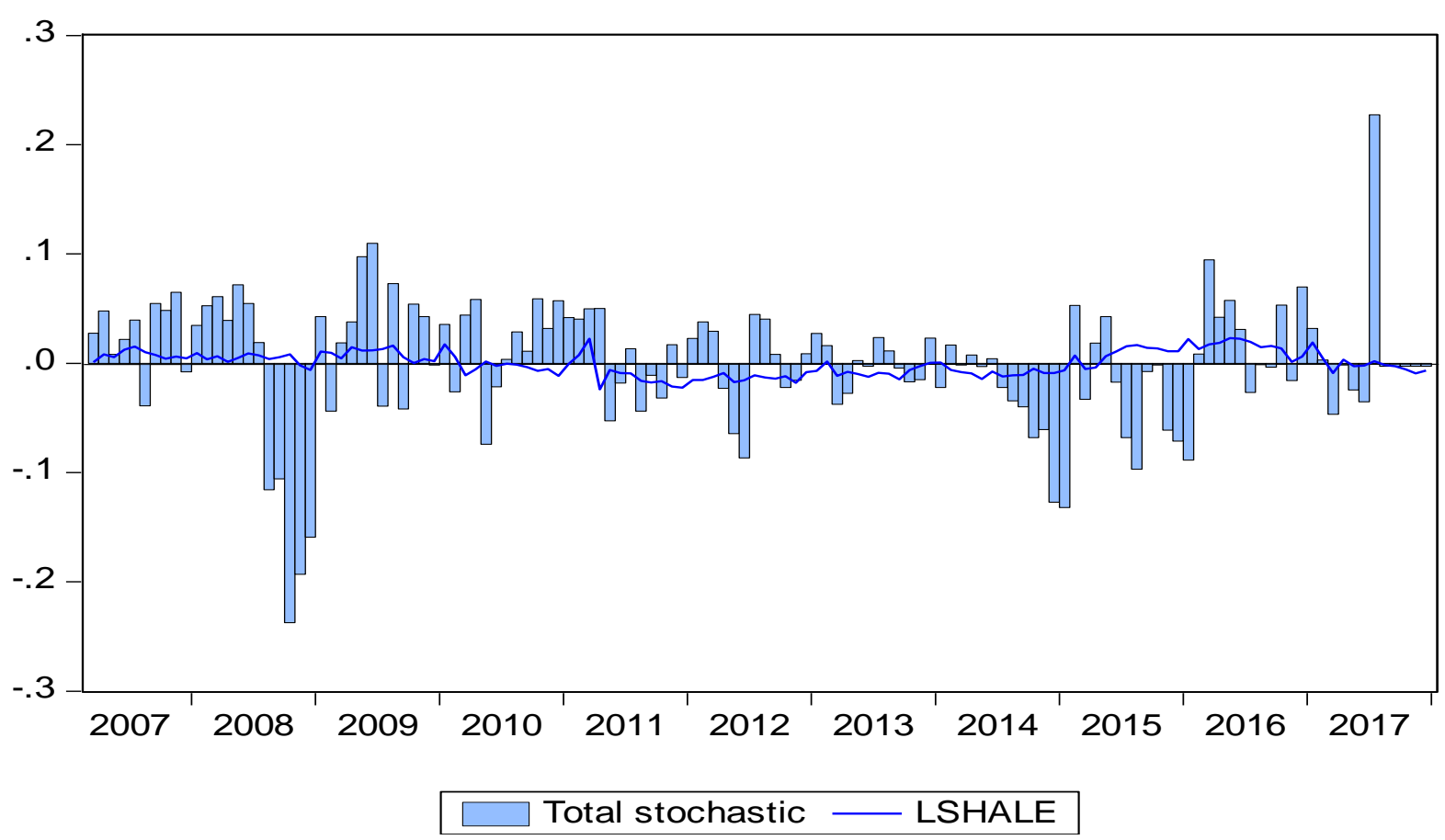

Figure 12: Historical Decomposition of Nonfuel Prices from Shale Oil

LNONFUEL from LSHALE

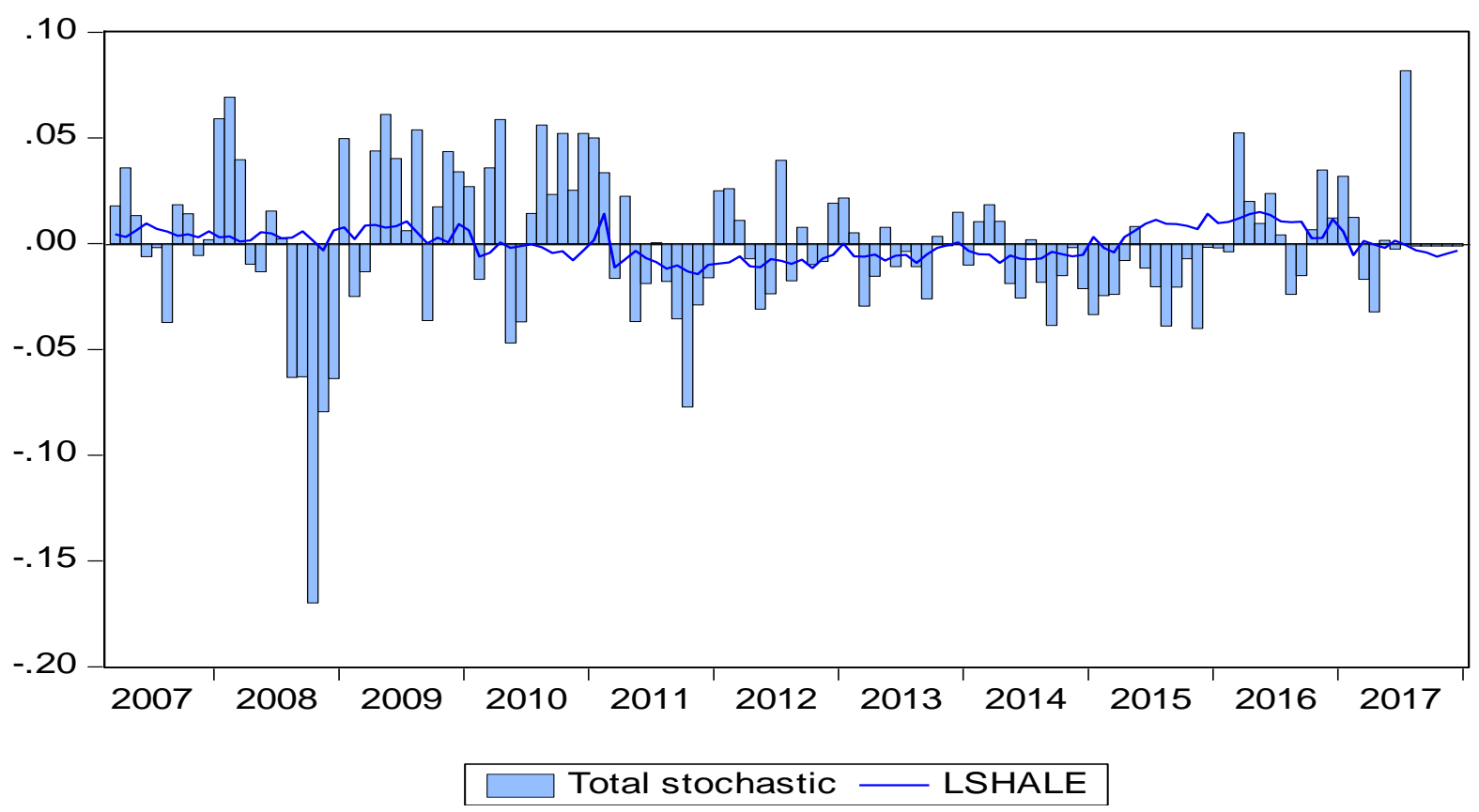


Table 1: Data Scope

\begin{tabular}{lccc}
\hline Variables & Start Date & End Date & No. \\
\hline US Shale Oil Production & $01 / 1 / 2007$ & $31 / 12 / 2017$ & 132 \\
US Crude Oil Production & $01 / 1 / 2007$ & $31 / 12 / 2017$ & 132 \\
WTI & $01 / 1 / 2007$ & $31 / 12 / 2017$ & 132 \\
Commodity Price Index (all) & $01 / 1 / 2007$ & $31 / 12 / 2017$ & 132 \\
Commodity Price Index (non-fuel) & $01 / 1 / 2007$ & $31 / 12 / 2017$ & 132 \\
\hline
\end{tabular}

Table 2: Summary Statistics

\begin{tabular}{|c|c|c|c|c|c|}
\hline Variables & Mean & Std. Dev. & Skewness & Kurtosis & Jarque-Bera \\
\hline US Shale Oil Production & 3386.923 & 1779.642 & 0.209151 & 1.357023 & $\begin{array}{l}15.8089^{* * *} \\
(0.00036)\end{array}$ \\
\hline US Crude Oil Production & 212722.8 & 53863.95 & 0.271639 & 1.467636 & $\begin{array}{l}14.5381^{* * *} \\
(0.00069)\end{array}$ \\
\hline WTI & 75.98227 & 23.90436 & 0.014113 & 2.020951 & $\begin{array}{l}5.2763^{*} \\
(0.07149)\end{array}$ \\
\hline Commodity Prices (all) & 149.9644 & 35.29284 & -0.039890 & 1.702526 & $\begin{array}{l}9.2939^{* * *} \\
(0.00959)\end{array}$ \\
\hline Commodity Prices (non-fuel) & 153.1948 & 21.26639 & 0.249284 & 2.636638 & $\begin{array}{l}2.09331 \\
(0.35110)\end{array}$ \\
\hline
\end{tabular}

Note: values in "()" parenthesis are probability values associated with the respective statistics. The symbol *** indicates $1 \%$ level of significance. 


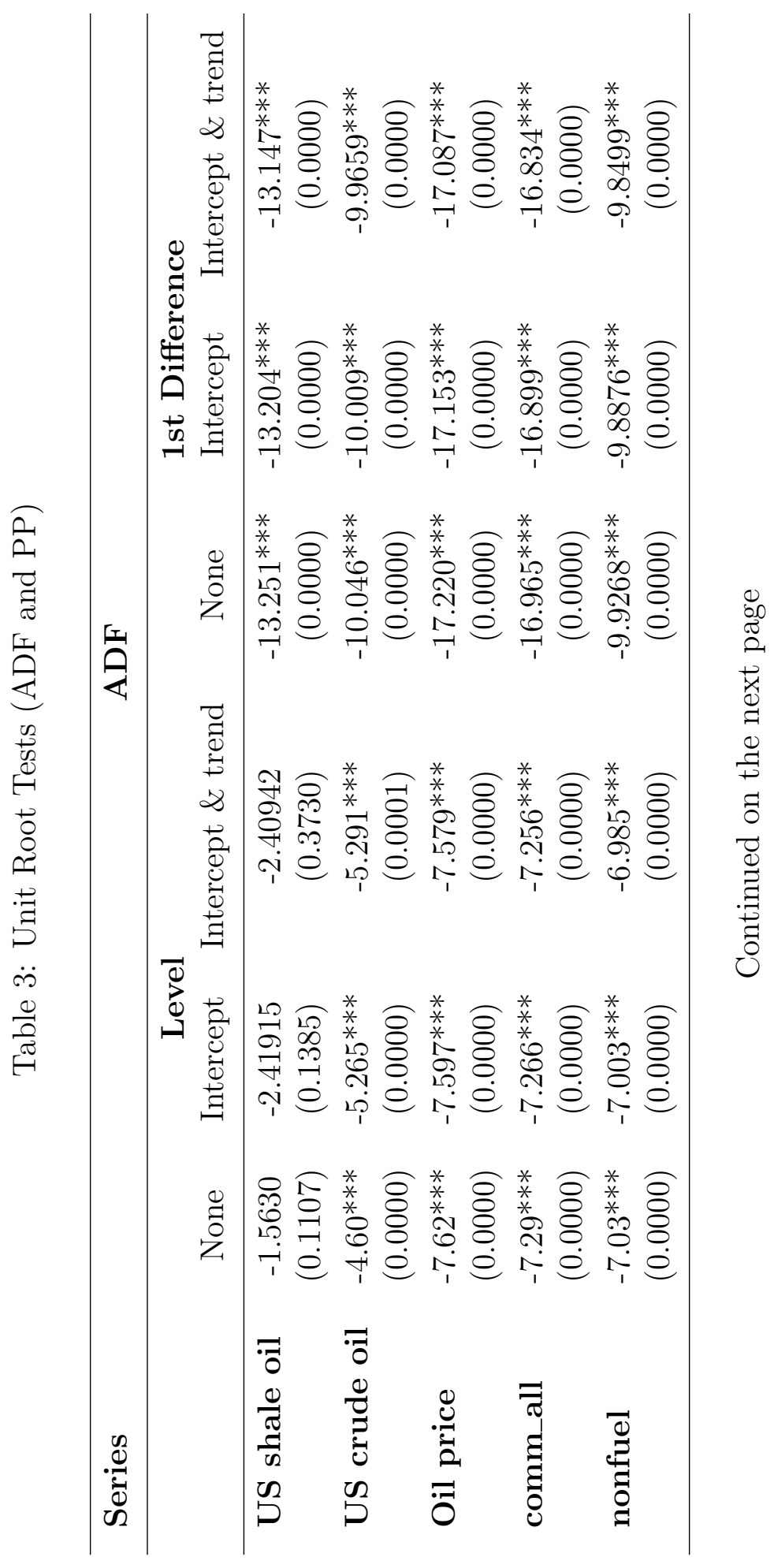




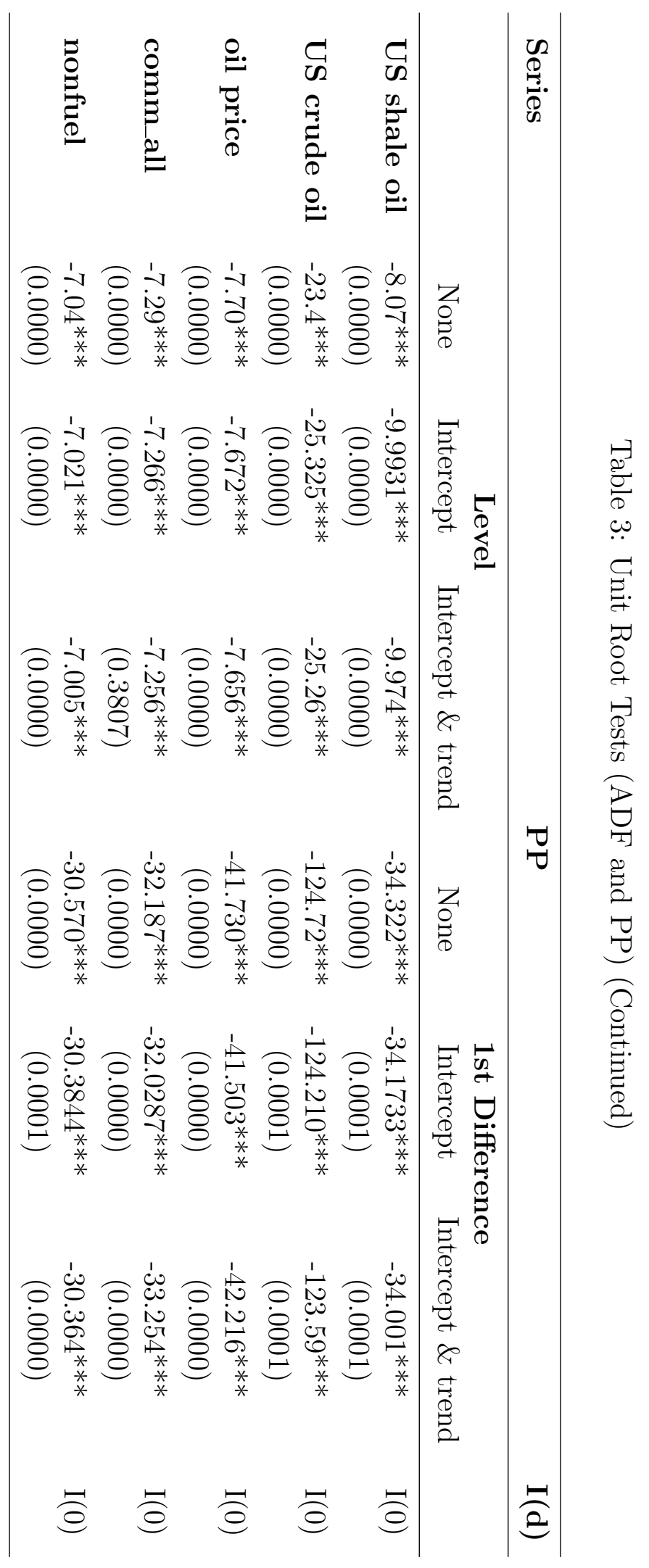




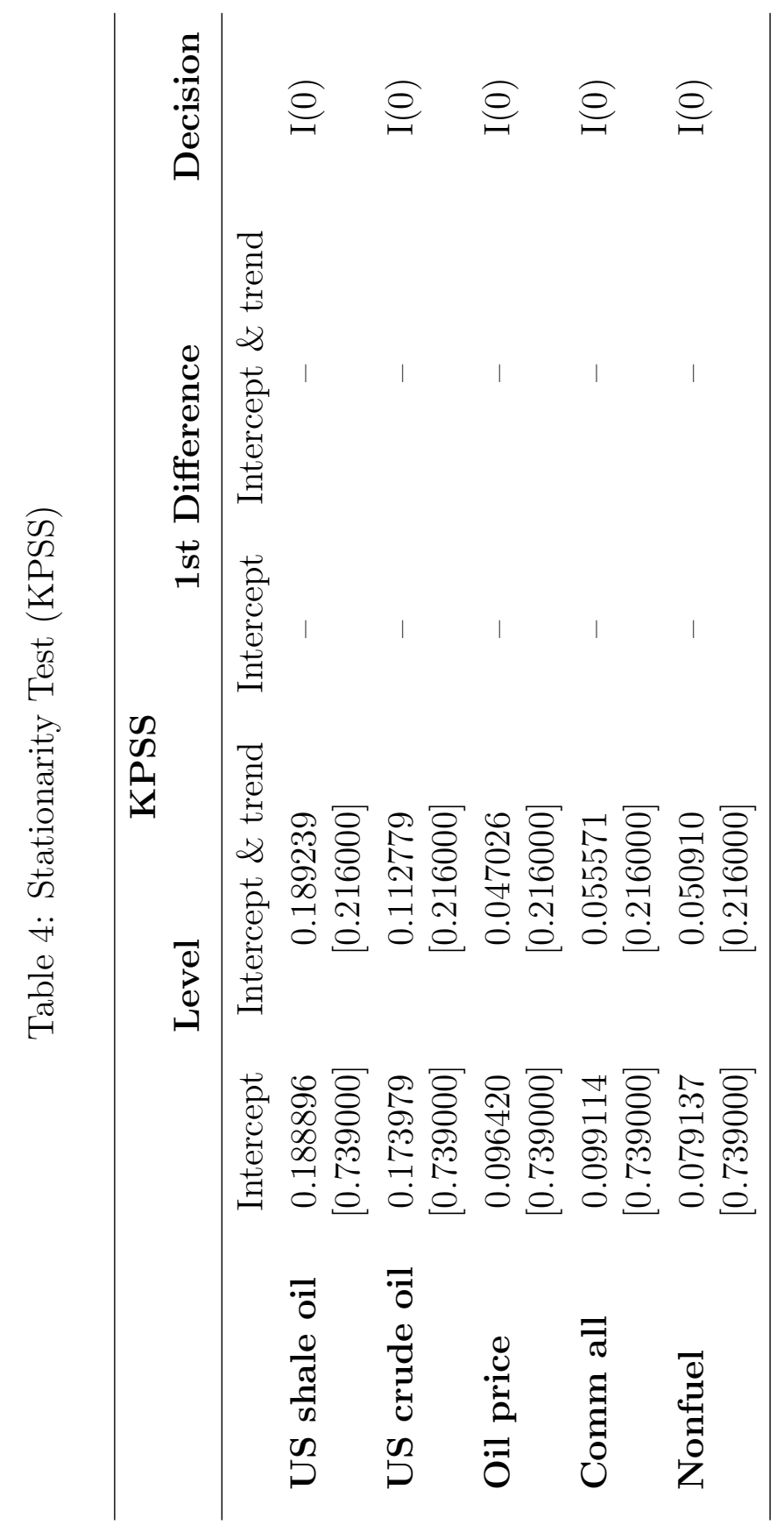


Table 5: Variance decomposition from shale oil supply up to commodity prices

\begin{tabular}{cccccc}
\hline Period & S.E. & $\begin{array}{c}\text { Shock1 } \\
\text { (Shale Oil) }\end{array}$ & $\begin{array}{c}\text { Shock2 } \\
\text { (Crude Oil) }\end{array}$ & $\begin{array}{c}\text { Shock3 } \\
\text { (Oil Price) }\end{array}$ & $\begin{array}{c}\text { Shock3 } \\
\text { (Comm Price) }\end{array}$ \\
\hline 1 & 0.016744 & 100.0000 & 0.000000 & 0.000000 & 0.000000 \\
2 & 0.017786 & 97.12061 & 2.721146 & 0.014104 & 0.144136 \\
3 & 0.017855 & 96.83088 & 2.721146 & 0.034232 & 0.204710 \\
4 & 0.017873 & 96.68458 & 3.066039 & 0.040340 & 0.209043 \\
5 & 0.017877 & 96.64657 & 3.100263 & 0.042317 & 0.210849 \\
6 & 0.017878 & 96.63503 & 3.111451 & 0.042645 & 0.210872 \\
7 & 0.017878 & 96.63126 & 3.115087 & 0.042731 & 0.210926 \\
8 & 0.017878 & 96.63018 & 3.116153 & 0.042741 & 0.210924 \\
9 & 0.017878 & 96.62982 & 3.116509 & 0.042744 & 0.210926 \\
10 & 0.017878 & 96.62972 & 3.116614 & 0.042744 & 0.210925 \\
11 & 0.017878 & 96.62968 & 3.116649 & 0.042744 & 0.210926 \\
12 & 0.017878 & 96.62967 & 3.116659 & 0.042744 & 0.210926 \\
\hline
\end{tabular}


Table 6: Variance decomposition from shale oil supply up to nonfuel prices

\begin{tabular}{cccccc}
\hline Period & S.E. & $\begin{array}{c}\text { Shock1 } \\
\text { (Shale Oil) }\end{array}$ & $\begin{array}{c}\text { Shock2 } \\
\text { (Crude Oil) }\end{array}$ & $\begin{array}{c}\text { Shock3 } \\
\text { (Oil Price) }\end{array}$ & $\begin{array}{c}\text { Shock3 } \\
\text { (Comm Price) }\end{array}$ \\
\hline 1 & 0.016754 & 100.0000 & 0.000000 & 0.000000 & 0.000000 \\
2 & 0.017793 & 97.12178 & 2.814805 & 0.027369 & 0.036042 \\
3 & 0.017857 & 96.92635 & 2.994879 & 0.037070 & 0.041700 \\
4 & 0.017875 & 96.79445 & 3.123130 & 0.040145 & 0.042270 \\
5 & 0.017878 & 96.76415 & 3.151815 & 0.040728 & 0.043304 \\
6 & 0.017878 & 96.75453 & 3.161254 & 0.040882 & 0.043331 \\
7 & 0.017879 & 96.75155 & 3.164116 & 0.040906 & 0.043425 \\
8 & 0.017879 & 96.75073 & 3.164924 & 0.040913 & 0.043428 \\
9 & 0.017879 & 96.75047 & 3.165184 & 0.040913 & 0.043436 \\
10 & 0.017879 & 96.75039 & 3.165257 & 0.040914 & 0.043436 \\
11 & 0.017879 & 96.75037 & 3.165280 & 0.040914 & 0.043437 \\
12 & 0.017879 & 96.75036 & 3.165287 & 0.040914 & 0.043437 \\
\hline
\end{tabular}

